\title{
Antinociceptive Activity of the Natural Piperidine Alkaloid Hydrochlorides from Syphocampylus verticellatus
}

Obdulio G. Miguel $^{\mathrm{a}}$, Adair R. S. Santos ${ }^{\mathrm{b}}$, João B. Calixto ${ }^{\mathrm{b}}$, Franco Delle Monache and Rosendo A. Yunes ${ }^{\mathrm{d}, *}$

a Departamento de Farmacia, Universidade Federal do Paraná, Curitiba, Brazil

b Departamento de Farmacologia, Universidade Federal de Santa Catarina, Rua Ferreira Lima, 82, 88015-420 - Florianópolis, SC, Brazil

c Centro Chimica Recettori, CNR, Rome, Italy

d Departamento de Química, Universidade Federal de Santa Catariana, 88040-900, Florianópolis, SC, Brazil. Fax: (48) 331-9711. E-mail: ryunes@qmc.ufsc.br

* Author for correspondence and reprint requests

Z. Naturforsch. 57c, 81-84 (2002); received August 10/October 12, 2001

Syphocampylus verticellatus, Alkaloids Hydroclorides, Antinociceptive Activity

In addition to $3^{\prime}$-methoxyluteolin and mixtures of sterols and triterpenes, the leaves of Syphocampylus Verticellatus yielded two piperidine alkaloid hydrochlorides, one of them has a novel structure. The alkaloids exhibit antinociceptive activity.

\section{Introduction}

Syphocampylus verticillatus is a small strub widely distributed at the border of the rivulets of the Paraná State (Brazil) whose leaves are used in the folk medicine (Correa 1931). In a previous paper (Miguel et al., 1996) we described the Xray structure determination of the main alkaloid occurring in the plant as hydrochloride. Successively, from the same plant, Biavatti (Biavatti et al., 1998) reported the same alkaloid, isolated as free base, depending from the isolation process involving alkalinization of the extract.

Pharmacological studies have shown (Trentin et al., 1997) that the hydroalcoholic extract of the leaves exhibits dose-related antinociceptive activity in several models of nociception in mice. Owing to the considerable pharmacological interest (Santos et al., 1999) of that extract we have re-examined its composition. This paper describes the isolation of a second novel piperidine alkaloid hydrochloride and other components of leaves, as well as the antinociceptive activity of both alkaloid hydrochlorides.

\section{Material and Methods}

\section{Plant material}

The leaves of Syphocampylus verticellatus (Campanulaceae) were collected in January in São
José dos Pinhais near to Curitiba, Paraná. The plant was identified by Gert Hatschbach Director of the Museu Botánico Municipal (Curitiba). Voucher specimens are deposited in the Herbario Municipal (Curitiba) under the cipher 68920.

\section{Isolation and identification}

Air dried leaves $(10 \mathrm{~kg})$ were powdered and macerated with $95 \%$ methanol at room temperature for approximately 14 days. After solvent removal under reduced pressure the extract was then suspended in water and successively partitioned with $500 \mathrm{ml}$. of each one of the following solvents: hexane, chloroform, ethyl acetate and butanol, respectively.

Part of the dry hexane fraction $(5 \mathrm{~g})$ was chromatographed on a silica gel column eluted with hexane-ethyl acetate gradient giving $320 \mathrm{mg}$ of a mixture of stigmasterol, $\beta$-sitosterol and campesterol $(77 \%, 20 \%$, and $3 \%$, respectively) and $20 \mathrm{mg}$ of a mixture of $\alpha$ - and $\beta$-amyrin $(60 \%$ and $40 \%$, respectively) that were determined by GC-MS.

Part of the dry ethyl acetate fraction $(10 \mathrm{~g})$ was chromatographed on a silica gel column eluted with a gradient of methanol in ethyl acetate yielding $\beta$-sitosterol glucoside $(24 \mathrm{mg})$ which was identified on the basis of NMR spectra data in comparison with those of an authentic sample available in our laboratory, and $3^{\prime}$-methoxy-luteolin (17 mg) 
that exhibits NMR spectra (in $\mathrm{C}_{5} \mathrm{D}_{5} \mathrm{~N}$ ) comparable to those of literature in dmso-d6 (Sakakibara et al., 1976; Wagner et al., 1976). The location of the OMe group was confirmed by a difference NOE experiment.

The dry $n$-butanol soluble portion $(51.5 \mathrm{~g})$ of the extract was adsorbed on silica gel washed with ethyl acetate, and then eluted with methanol. After evaporation of the methanol the fraction was chromatographed on silica gel column eluted with a gradient of methanol in ethyl acetate. The fractions eluted with MeOH:EtOAc 1:1 v/v afforded the alkaloid chloride $2(100 \mathrm{mg})$ and $\mathbf{1}$ (3 g) successively.

\section{$3^{\prime}$-Methoxy luteolin}

${ }^{1} \mathrm{H}$ NMR (300 MHz, $\left.\mathrm{C}_{5} \mathrm{D}_{5} \mathrm{~N}\right), \delta 13.83$ (s, OH-5), $7.66(\mathrm{dd}, J=8.3$ and $2.0 \mathrm{~Hz}$; H-6), $7.62(\mathrm{~d}, J=2.0$ Hz; H-2), 7.29 (d, $J=8.3 \mathrm{~Hz}$; H-5'), 7.0 (s, H-2), $6.88(\mathrm{~d}, J=2.1 \mathrm{~Hz} ; \mathrm{H}-6), 6.78(\mathrm{~d}, J=2.0 \mathrm{~Hz}$; $\mathrm{H}-8$ ), 3.83 (s, OMe-3'). Difference NOE experiment: the selective irradiation at $\delta 3.87$ (OMe-3') enhanced the signal at $\delta 7.62\left(\mathrm{H}-2^{\prime}\right) .{ }^{13} \mathrm{C} \mathrm{NMR}$ $\left(75 \mathrm{MHz}, \mathrm{C}_{5} \mathrm{D}_{5} \mathrm{~N}\right), \delta 182.5$ (C-4), 165.7 (C-7), 164.3 (C-2), 162.9 (C-9), 158.3 (C-5), 152.4 (C-4'), $148.7\left(\mathrm{C}-3^{\prime}\right), 122.1\left(\mathrm{C}-1^{\prime}\right), 121.1\left(\mathrm{C}-6^{\prime}\right), 116.7$ (C-5'), 110.1 (C-2'), 104.7 (C-10), 104.0 (C-3), 99.8 (C-6), 94.7(C-8), 55.8 (OMe-3').

N-Methyl-2,6-bis-[2-hydroxy-pentyl)-piperidine hydrochloride, 1

White crystals, m.p. $75^{\circ} \mathrm{C}(\mathrm{MeOH})$. EI-MS, $m / z$ (rel. int.): $271\left[\mathrm{M}^{+}\right](6), 184$ (100), 98 (74), 96 (32). ${ }^{1} \mathrm{H}$ MNR (300 Mz, CDCl $), \delta$ 4.05-3.87 (m; H-2, H-6, H-8, H-8' $), 2.95$ (br s; OH), 2.68 (N-Me), $0.90\left(\mathrm{t}, J=7 \mathrm{~Hz} ; \mathrm{Me}-11, \mathrm{Me}-11^{\prime}\right) .{ }^{13} \mathrm{C}$ NMR $\left(75 \mathrm{MHz}, \mathrm{CDCl}_{3}\right), \delta 69.4\left(\mathrm{C}-8, \mathrm{C}-8^{\prime}\right), 64.1$ (C-2, C-6), 40.4 (C-7, C-7'), 37.6 (C-3, C-5), 26.1 (C-9, C-9'), 22.4 (C-4), 18.5 (C-10, C-10'), 14.0 (Me-11, $\left.\mathrm{Me}-11^{\prime}\right)$.

N-Methyl-2-(2-hydroxybutyl)-6-(2-hydroxypentylpiperidine), 2

White crystals, m.p. $55^{\circ} \mathrm{C}(\mathrm{MeOH})$. EI-MS, $m / z$ (rel. int.): $257\left[\mathrm{M}^{+}\right](11), 184\left[\mathrm{M}-\mathrm{C}_{4} \text { chain }\right]^{+}(57)$, $170\left[\mathrm{M}-\mathrm{C}_{5} \text { chain }\right]^{+}(100), 98$ (96). ${ }^{1} \mathrm{H}$ NMR (300 $\mathrm{MHz}, \mathrm{CDCl}_{3}$ ), $\delta$ 4.06-4.00 (m; H-8, H-8'), 3.963.86 (m; H-2, H-2'), $2.70(\mathrm{~s}, \mathrm{~N}-\mathrm{Me}), 0.93(\mathrm{t}, J=$
$7 \mathrm{~Hz}$; Me-10'), 0.90 (t, $J=7 \mathrm{~Hz}, \mathrm{Me}-10) .{ }^{13} \mathrm{C}$ NMR (75 MHz, $\mathrm{CDCl}_{3}$ ), 871.0 (C-8'), 69.4 (C-8), 64.4 (C-2, C-6), 40.6 (C-7, C-7'), 37.9 and 37.4 (C-3, C-5), 31.2 (C-9'), 26.1 (N-Me), 24.5 (C-9), 22.7 (C-4), 18.5 (C-10), 14.0 (Me-11), 9.7 (Me-10').

\section{The antinociceptive action in the formalin-induced pain}

Non-fasted male Swiss mice (25-35 g), housed at $22 \pm 2{ }^{\circ} \mathrm{C}$ under a 12-h light/12-dark cycle and with access to food and water ad libitum, were used throughout the experiments. The experiments reported were carried out in accordance with the current guidelines for the care of laboratory animals and the ethical guidelines for investigations of experimental pain in conscious animals according to Zimmermann (1983).

Experiments were carried out in according with previous described method (Trentin et al., 1997; Santos et al., 1999). Briefly, animals were injected intraplantarly with $20 \mu \mathrm{l}$ of $2.5 \%$ formalin solution ( $0.92 \%$ of formaldehyde), made up in phosphatebuffer solution (concentration: $\mathrm{NaCl} 137 \mathrm{~mm}, \mathrm{KCl}$ $2.7 \mathrm{~mm}$ and phosphate buffer $10 \mathrm{~mm}$ ), in the right hindpaw. Mice were treated with alkaloid by intraperitoneally (i.p., $10.2-102.3 \mu \mathrm{mol} / \mathrm{kg}$ ), intracerebroventricularly (i.c.v.) or intrathecally (i.t.) (34.1-341.2 nmol/site) as described previously (Santos and Calixto, 1997; Santos et al., 1999), 30, 25 and $15 \mathrm{~min}$ before formalin injection, respectively. Control animals received a similar volume of vehicle systemically (i.p., $10 \mathrm{ml} / \mathrm{kg}$ ) or centrally (i.c.v. or i.t., $5 \mu \mathrm{l} /$ site). When possible, the ID $_{50}$ values were determined by linear regression from individual experiments using linear regression "GraphPad" software.

The alkaloid given by i.p., i.t. or by i.c.v. routes produced dose-related antinociception when assessed against the both phases of the formalin-induced analgesic response. The calculated mean ID $_{50}$ values and the inhibition (\%) for these effects are presented in Table 1.

\section{Result and Discussion}

The hexane fraction, obtained from the partition of the crude methanol (95\%) extract of the dried leaves, showed the presence of $\beta$-sitosterol, stigmasterol, campesterol, $\alpha$ - and $\beta$-amirin that were 
identified by co-injection (HRGC) with authentic specimens.

The ethyl acetate fraction present $\beta$-sitosterol glycoside and 3'-methoxy luteolin identified specially by ${ }^{1} \mathrm{H}$ NMR, ${ }^{13} \mathrm{C}$ NMR and difference NOE experiment.

The butanol soluble fraction yielded two alkaloid hydrochlorides to which the structure $\mathbf{1}$ and $\mathbf{2}$ (Fig. 1) were attributed, respectively, on the basis of NMR data and for the main component (alkaloid 1) by X-ray diffraction method (Miguel et al., 1996). The assignment of the ${ }^{13} \mathrm{C}$ NMR signals followed by the comparison with the data of literature for piperidine hydrochlorides (Eliel et al., 1980) as well as for free piperidines (Krebs and Ramiarantsoa 1998; Eliel et al., 1980).

In Table 1 are compared the mean ID $_{50}$ values of both alkaloids for the antinociceptive action in the formalin model of pain. The behavior of both alkaloids was similar, however, while the alkaloid $\mathbf{1}$ gave a higher inhibition than alkaloid $\mathbf{2}$ on the second phase of the pain, alkaloid 2 seems more

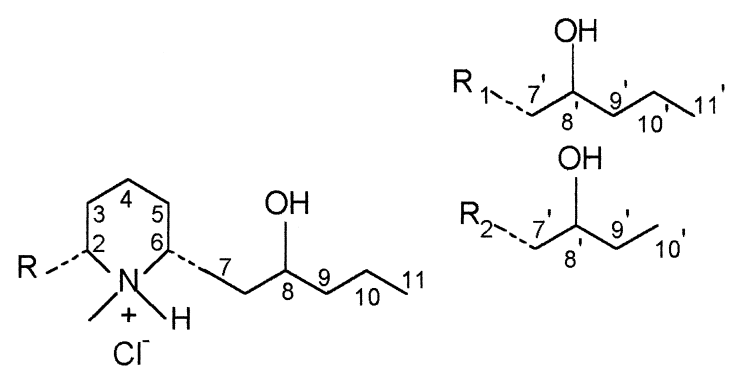

Fig. 1. Structures of alkaloid $\mathbf{1}\left(\mathrm{R}_{1}\right)$ and $\mathbf{2}\left(\mathrm{R}_{2}\right)$.

potent to inhibit the first phase corresponding to the neurogenic pain. This fact leads to believe that a study of structure and activity correlation should be important to obtain analogs with selective antinociceptive activity.

\section{Acknowledgements.}

The authors are grateful, for the financial support, to CNPq, PRONEX, FINEP from Brazil.

Table 1. Comparison of the mean $\operatorname{ID}_{50}$ values for the antinociceptive action of alkaloid 1 and alkaloid 2 isolated from Syphocampylus verticellatus in the formalin pain model.

\begin{tabular}{|c|c|c|c|c|c|}
\hline \multirow[b]{2}{*}{ Compound } & \multirow[b]{2}{*}{ Route } & \multicolumn{4}{|c|}{ Formalin test } \\
\hline & & Early phase $\left[\mathrm{ID}_{50}\right]^{\mathrm{b}}$ & Inhibition [\%] & Late phase $\left[\mathrm{ID}_{50}\right]^{\mathrm{b}}$ & Inhibition $[\%]$ \\
\hline \multirow[t]{3}{*}{ Alkaloid I ${ }^{\mathrm{a}}$} & i.p. $\quad(\mu \mathrm{mol} / \mathrm{kg})$ & n.d. & $36 \pm 5$ & $48.3(39.6-59.1)$ & $88 \pm 6$ \\
\hline & i.c.v. (nmol/site) & $146.1(114.9-193.6)$ & $52 \pm 3$ & $112.6(44.2-286.5)$ & $60 \pm 3$ \\
\hline & i.t. $\quad(\mathrm{nmol} / \mathrm{site})$ & $33.5(13.1-85.6)$ & $67 \pm 6$ & $56.2(25.3-125.7)$ & $74 \pm 4$ \\
\hline \multirow[t]{3}{*}{ Alkaloid II } & i.p. $(\mu \mathrm{mol} / \mathrm{kg})$ & $64.1 \quad(50.5-81.2)$ & $57 \pm 4$ & $51.2(32.4-80.5)$ & $59 \pm 7$ \\
\hline & i.c.v. (nmol/site) & $111.6 \quad(87.0-143.6)$ & $79 \pm 3$ & $69.9(63.1-77.8)$ & $79 \pm 4$ \\
\hline & i.t. $\quad(\mathrm{nmol} / \mathrm{site})$ & $259.7(222.5-302.3)$ & $53 \pm 5$ & $89.7(75.4-106.4)$ & $56 \pm 4$ \\
\hline
\end{tabular}

n.d., not determined. ${ }^{a}$ Data from Santos et al., $1999^{\mathrm{b}}$. The $\mathrm{ID}_{50}$ values represent the dose of compound that inhibit the pain response by $50 \%$ in relation to the control value.

Biavatti M. W., Brown R. T. and Santos C. A. M. (1998), Two piperidine alkaloids from Siphocampylus verticillatus. Phytochemistry 48, 747-749.

Correa M. P. (1931), Dicionario das plantas uteis no Brasil e das exoticas cultivadas, Vol. 2, 404. Ministerio de Agriculatura, Rio de Janeiro, Brazil.

Eliel E. L. Kandasamy D., Yen C. Y. and Hargrave K. D. (1980), Conformational-Analysis .39.C-13 NMRspectra of saturated heterocycles.9. piperidine and N-methylpiperidine. J. Am. Chem. Soc. 102, 36983707.

Krebs H. C. and Ramiarantsoa H. (1998), Piperidine alkaloids and other constituents of Dialypetalum floribundum. Phytochemistry 48, 911-913.

Miguel O. G., Vencato I., Pizzolatti M. G., Calixto J. B. and Santos C. A. M. (1996), cis-8,10-Di- $n$-propyllobe- lidiol hydrochloride dehydrate. Acta Cryst. C52, $1232-1225$.

Sakakibara M, Difeo D., Nakatani N., Timermann B. and Mabry T. J. (1976), Flavonoid methyl ethers on external leaf surface of Larrea tridentata and Larrea divaricata. Phytochemistry 15, 727-731.

Santos A. R. S. and Calixto J. B. (1997), Further evidence for the involvement of tachykinin receptor subtypes in formalin and capsaicin models of pain in mice. Neuroptides 31,381-389.

Santos A. R. S., Miguel O. G., Yunes R. A. and Calixto J. B., (1999), Antinociceptive properties of the new alkaloid, cis-8,10-di- $n$-propyllobelidiol hydrochloride dehydrate isolated from Siphocampylus verticillatus: evidence for the mechanism of action. J. Pharmacol. Exp. Ther. 289, 417-426. 
Trentin A. P., Santos A. R. S., Miguel O. G., Pizzolatti M. G., Yunes R. A. and Calixto J. B. (1997), Mechanisms involved in the antinociceptive effect in mice of the hydroalcoholic extract of Siphocampylus verticillatus. J. Pharm. Pharmacol. 49, 572-576.
Wagner H., Chari V. M., and Sonnenbichler J. (1976), C-13 NMR-spectra of natural flavonoids. Tetrahedron Lett., 1799-1802.

Zimmermann M. (1983), Ethical guidelines for investigations os experimental pain in conscious animals. Pain 16, 109-110. 